\title{
Effects of heavy metals on the oyster (Crassostrea virginica) at Mandinga Lagoon, Veracruz, Mexico
}

\author{
X. Guzmán-García ${ }^{1}$, A.V. Botello², L. Martinez-Tabche ${ }^{4}$ \& H. González-Márquez ${ }^{3}$ \\ 1. Laboratory of Ecotoxicology, Hidrobiology Departament, UAM-I, Av. San Rafael Atlixco No. 186 Col. Vicentina, \\ Iztapalapa, C.P. 09340, Mexico. Fax: 5804 4738; xgg@xanun.uam.mx \\ 2. Marine Pollution Laboratory, Instituto de Ciencias del Mar y Limnología, UNAM, Mexico. \\ 3. Laboratory of Gen Expression, Health Sciences, UAM-I, Av. San Rafael Atlixco No. 186 Col. Vicentina, Iztapalapa, \\ C.P. 09340, Mexico. \\ 4. Laboratory of Aquatic Toxicology, Pharmacy Departament, ENCB, IPN, Mexico.
}

Received 15-V-2008. Corrected 05-III-2009. Accepted 07-IV-2009

\begin{abstract}
The Mandinga Lagoon in the Mexican State of Veracruz is an important ecological zone that produces $32 \%$ of the oyster output in the state of Veracruz, the main oyster producer in Mexico. Samples of water, sediment, and oysters were collected in 2003 and 2004 to study heavy metal pollution. Metal concentrations were determined in water, soil, and oyster tissues from fresh and detoxified Crassostrea virginica, and histology samples were analyzed. Metal $(\mathrm{Cr}, \mathrm{Cd}$, and $\mathrm{Pb})$ concentrations in water were within the Mexican legal limits. The recorded values in sediments corresponded to those not producing biological effects (ERL). In the tissues, the highest concentrations corresponded to $\mathrm{Pb}$, above $5.84 \mu \mathrm{gg}^{-1}$ dry weight (d.w.); Cd was of $2.23 \mu \mathrm{gg}^{-1}$ d.w., and $\mathrm{Cr}$ above $6 \mu \mathrm{gg}^{-1} \mathrm{~d}$.w. The metal levels detected in oysters exceeded the maximum permissible limits (MPL) for $\mathrm{Cd}$ and $\mathrm{Pb}$, and oysters were unable to eliminate the concentrations of the bioaccumulated metals during the detoxification stage. The histopathological analysis revealed lesions in the digestive gland, edema, atrophy of epithelia in the digestive tubules, the presence of brown vesicles, hemocytic reaction, and necrosis. During detoxification, a higher number of epithelia were observed in the tubules, as well as an increase in brown vesicles and hemocytic reaction. Forty seven percent of oysters presented histopathological lesions related to metal concentrations. It is important to monitor metal concentrations, to detect the source of pollution, andto evaluate the effects on organisms to establish culture areas and adequate criteria for the exploitation of such an important fishery resource. Rev. Biol. Trop. 57 (4): 955-962. Epub 2009 December 01.
\end{abstract}

Key words: cadmium, chromium, heavy metals, histopathological damage, oyster.

The Mandinga Lagoon in the Mexican State of Veracruz is an important ecological zone, which, in economical terms, sustains a high oyster production, as it contributes $32 \%$ of the oyster production in the whole state of Veracruz, the first oyster producer in Mexico. Reports indicate that the oyster production markedly decreased in this region from 1991 to 1996 (Palacios Fest \& Vargas Rancel 2002). In addition, the presence of pollution-related events have been demonstrated and the levels of pollutants have been assessed; this data has shown that heavy metals, mainly $\mathrm{Cr}, \mathrm{Cd}$, and
$\mathrm{Pb}$, as well as hydrocarbons and pesticides, stand out, caused by the runoff of household and industrial discharge in the area (Villanueva \& Botello 1998).

Pollution monitoring in aquatic systems has been limited to determining the pollutant levels in the tissues of organisms, with little attention to the physical alterations produced by them (Gold-Bouchot et al. 1997). However, some authors believe that metal concentrations in the biota are better indicators of the biological impact than the environmental concentrations, because the organisms incorporate the 
contaminants into their bioavailable fraction (Borgmann \& Norwood 2002). Therefore, the oyster Crassostrea virginica has been proposed for the study of the integration of contaminants (Luna et al. 2002). Physiological changes in bivalves are a sign of alterations in the rates of filtration, feeding, growth, respiration, and reproduction, as well as in changes in their metabolic and biochemical parameters (Chavin 1973). Assessment of changes produced by pollutants in organs/tissues can be done before an irreversible effect appears on the biota, becoming an "alarm system" of great relevance in protecting species, as well as the environment. Hence, the aim of this study was to determine the levels of toxic metals $(\mathrm{Pb}, \mathrm{Cr}$, and $\mathrm{Cd})$ in the water, sediment, and oyster of the Mandinga Lagoon in Veracruz, and to determine their histopathological effects on natural oysters and on oysters subjected to detoxification under laboratory conditions.

\section{MATERIALS AND METHODS}

This study was performed in the Mandinga lagoon, located in the Gulf of Mexico, in the south of the State of Veracruz, between parallels $19^{\circ} 00^{\prime}$ to $19^{\circ} 06^{\prime} \mathrm{N}$ and meridians $96^{\circ} 02^{\prime}$ to $96^{\circ} 06^{\prime} \mathrm{W}$.

Samples of water, sediment, and oysters were collected in March, June, and October 2003 and in January and May 2004 in three different locations. In each, 15 oysters were collected for the determination of metals $(\mathrm{Cr}$, $\mathrm{Cd}$, and $\mathrm{Pb}$ ), 15 for histopathological studies, 20 for biometric studies, and 40 were transported to the laboratory for their detoxification and evaluation of the histopathological changes and metals content.

The oysters transported to the laboratory were placed in four $40 \mathrm{~L}$ experimental devices for $504 \mathrm{~h}$ with artificial Instant Ocean water (Shumway \& Koehn 1982); they were fed with laboratory cultures of Tetraselmis suecica (from 1 to 15 million cells $/ \mathrm{mL}$ ); ((SEPESCASecretaría de Pesca 1988, Castrejón et al. 1994) and were kept under optimal conditions. During the detoxification period, the $\mathrm{pH}$ (7.9), temperature $\left(25^{\circ} \mathrm{C}\right)$, salinity $(22 \mathrm{ppm})$, feeding (10 $000 \mathrm{cel} / \mathrm{mL})$, dissolved oxygen $(7.3 \mathrm{mg} / \mathrm{L})$, and ammonium content $\left(\mathrm{NH}_{3}: 4.8 \mu \mathrm{M} / \mathrm{L}\right)$ were continuously monitored and kept constant.

For the histological techniques, three oyster were collected every 72 hours, fixed in $10 \%$ formalin for $24 \mathrm{~h}$, then included in paraffin (tissue processor Leica TP1020, inclusion center Leica EG1140H), and three $9 \mu \mathrm{m}$ serial sections were done with a rotator microtome (Microm-Zeiss, model HM-315). Assessments were focused on the digestive system, the digestive gland, the gonad, and the connective tissue; preparations were hematoxylin-eosin stained (Howard \& Smith 1983).

For metal determinations, organisms were weighed and dehydrated. Metals were analyzed in oyster tissue with the method proposed by the International Atomic Enery Agency (IAEA) (1984), in water with Environmental Protection Agency (EPA) methodology (1984), and in sediments according to Agemian \& Chau (1976), modified by Malo (1977) and PáezOsuna (1993). The analytical procedure was corroborated with reference material (IAEA407 and GBW-08301). Known standards were used to build the pattern curve of each metal analyzed in an atomic absorption spectrophotometer (Shimadzu, Mod. AA-6800), using hollow cathode lamps.

Biometrics, which consisted of determining the length of the organisms and their fresh weight, were determined individually and the condition index was calculated (Mann 1978, Hetzel \& Wright 1983, Lucas \& Beninger 1985).

The functional relation was calculated from an average of the variables to minimize the influence of abiotic variables and biotic factors (Krishnakumar et al. 1994). Contingency tables and correlation indices were also calculated (Everitt 1992).

\section{RESULTS}

Metals determination and biometric parameters: Table 1 shows the average values of salinity, shell length, fresh tissue weight and 
TABLE 1

Average of physicochemical parameters and biometrics of the collected oysters, Mandinga Lagoon, Veracruz, Mexico

$\begin{array}{lcccccccc}\text { Sampling } & \begin{array}{c}\text { Salinity } \\ (\%)\end{array} & \mathrm{pH} & \begin{array}{c}\text { Physicochemical } \\ \text { Dissolved oxygen } \\ (\mathrm{mg} / \mathrm{L})\end{array} & \begin{array}{c}\text { Temperature } \\ \left({ }^{\circ} \mathrm{C}\right)\end{array} & \begin{array}{c}\text { Length } \\ (\mathrm{mm})\end{array} & \begin{array}{c}\text { Weight } \\ (\mathrm{g})\end{array} & \begin{array}{c}\text { Biometric } \\ \text { *Condition } \\ \text { Index }\end{array} \\ \text { March, 2003 } & 24.0 & 7.2 & 9.6 & 28.5 & 6.6 & 4.5 & 136 \\ \text { June, 2003 } & 30.0 & 7.6 & 7.0 & 31.0 & 7.2 & 10.7 & 285 \\ \text { October,2003 } & 22.3 & 7.8 & 6.6 & 25.0 & 6.8 & 15.2 & 276 \\ \text { January, 2004 } & 12.0 & 7.5 & 7.0 & 29.4 & 7.6 & 4.3 & 236 \\ \text { May, 2004 } & 22.3 & 8.3 & 7.0 & 24.5 & 6.6 & 9.0 & 194\end{array}$

- $\quad$ Condition Index = 90 (normal); 120 (high); 70 - 80 (low).

- $\quad$ Physicochemical values are mean of 3 independent samples

- Biometrics values are mean of 40 measurements.

condition index. The lower weight oysters were collected in March 2003 and January 2004, the remaining biometric parameters were similar during all sample collections, and their weights and indexes were acceptable from the allometric point of view.

Metal concentrations in the water of the lagoon remained within the levels recommended by the Mexican legislation (Table 2), except in October when Cd water levels of 1.86 $\mathrm{mg} \cdot \mathrm{L}^{-1}$ were recorded, exceeding the maximum permissible limit (MPL). Cr levels were $0.93 \mathrm{mg} \cdot \mathrm{L}^{-1}$, very close to the MPL. These findings could be due to removal of pollutants during the rainy season (Fig. 1).

In the sediment, the recorded metal values did not reach biological effect levels (ERL); $\mathrm{Cr}$ levels reached $40 \mu \mathrm{g}^{\bullet} \mathrm{g}^{-1}$, which are below those reported to generate biological effects. However, in March and June, Cd levels reached 0.97 and $1.24 \mu \mathrm{g}^{\circ} \mathrm{g}^{-1}$ respectively, which exceeded the ERL concentrations proposed by Long et al. (1995) (Fig. 2).

Average metal concentrations in the oyster were $2.23 \mu \mathrm{g}^{\bullet} \mathrm{g}^{-1} \mathrm{~d}$.w. for $\mathrm{Cd}$ and $5.84 \mu \mathrm{g}^{\bullet} \mathrm{g}^{-1}$ d.w. for $\mathrm{Pb} ; 13.41$ and $18 \mu \mathrm{g}^{\bullet} \mathrm{g}^{-1}$ d.w. for $\mathrm{Cr}$

TABLE 2

Concentration of metals in water, sediment, and oysters from the Mandinga Lagoon, Veracruz, Mexico

\begin{tabular}{lcccccccccc} 
Date & \multicolumn{3}{c}{ Water $(\mathrm{mg} / \mathrm{L})$} & \multicolumn{3}{c}{ Sediment $(\mu \mathrm{g} / \mathrm{g})$} & \multicolumn{3}{c}{ Oyster $(\mu \mathrm{g} / \mathrm{g}$ d.w. $)$} \\
& $\mathrm{Cd}$ & $\mathrm{Pb}$ & $\mathrm{Cr}$ & $\mathrm{Cd}$ & $\mathrm{Pb}$ & $\mathrm{Cr}$ & $\mathrm{Cd}$ & $\mathrm{Pb}$ & $\mathrm{Cr}$ \\
March, 2003 & 0.02 & 0.23 & 0.32 & 0.97 & 26.59 & 29.81 & 0.95 & 4.11 & 18.72 \\
June, 2003 & 0.07 & 0.25 & 0.19 & 1.24 & 22.27 & 44.28 & 6.23 & 12.01 & 13.41 \\
October, 2003 & 1.86 & D.L. & 0.93 & D.L. & 29.18 & 18.71 & 0.35 & 4.12 & D.L. \\
January, 2004 & D.L. & 2.59 & D.L. & D.L. & 4.90 & 3.09 & 2.89 & 4.91 & D.L. \\
May, 2004 & D.L. & 3.14 & D.L. & D.L. & 3.00 & 1.34 & 0.71 & 4.04 & D.L. \\
Average & 0.39 & 1.24 & 0.28 & 0.44 & 17.19 & 19.44 & 2.23 & 5.84 & 6.43 \\
**S.D. & \pm 0.73 & \pm 1.33 & \pm 0.34 & \pm 0.54 & \pm 11.05 & $\pm 16,24$ & \pm 2.18 & \pm 3.10 & \pm 8.04 \\
L.M.P & 0.9 & 6.00 & 1.00 & $1.20^{* *}$ & 46.70 & 81.00 & 0.50 & 1.00 & $13.00^{*}$
\end{tabular}

D.L. $=$ Detection limit (Cd, 0.236 $\mu \mathrm{g} / \mathrm{g} ; \mathrm{Pb}, 0.119 \mu \mathrm{g} / \mathrm{g} ; \mathrm{Cr}, 0.034 \mu \mathrm{g} / \mathrm{g})$.

L.M.P.= Maximum permissible limits, F.A.O. (Nauen 1983), NOM-031-SSA1-1993.

* Level of concentration $(\mu \mathrm{g} / \mathrm{g})$. Critical levels for consumption of bivalve molluscs.

** Sediment values producing biological effects (ERL), (22).

**S.D. $=$ Standard Deviation 


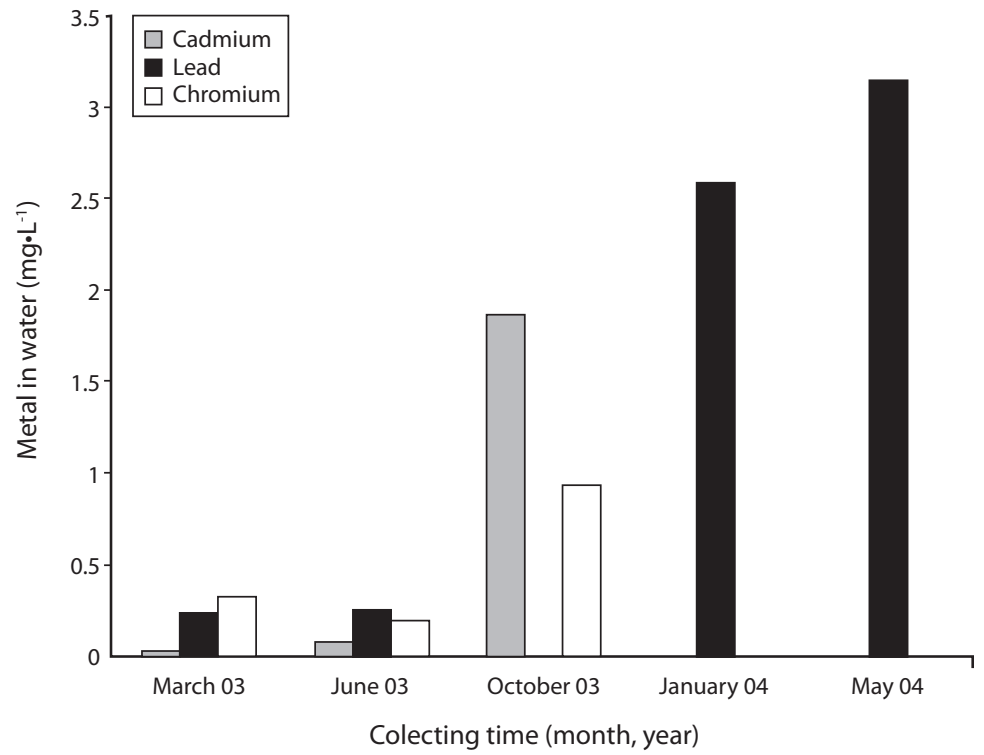

Fig. 1. $\mathrm{Cd}, \mathrm{Pb}$, and $\mathrm{Cr}$ concentrations in the water of the Mandinga Lagoon, Veracruz, Mexico.

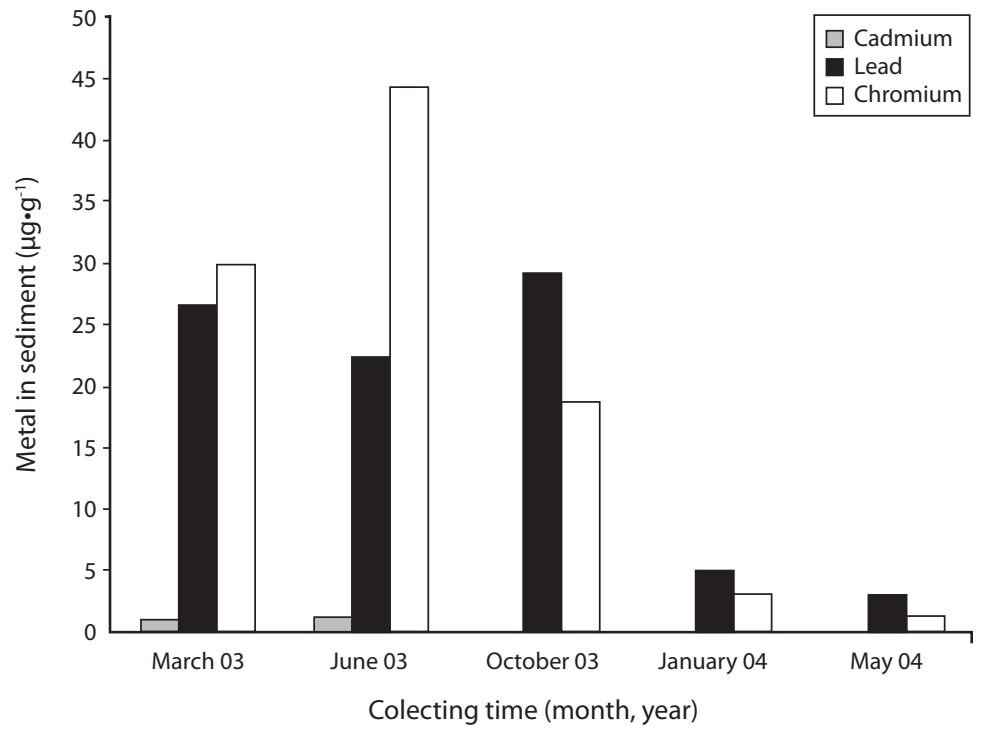

Fig. 2. Concentration of metal in the sediment of the Mandinga Lagoon, Veracruz, Mexico. 
(March and June 2003, respectively), exceeding the MPL. The highest metal concentrations recorded were for oysters collected in June, with high temperatures and low water levels, corresponding to the end of the dry season. Figure 3 shows the concentrations and the permanence of $\mathrm{Pb}$ and $\mathrm{Cd}$ recorded in the oyster along the annual cycle.

The matrix correlating the biometric parameters (length, weight, and condition index) vs. environmental parameters and pollutant concentrations is presented in Table 3. A high correlation was observed between $\mathrm{Cd}$ and $\mathrm{Cr}$ levels in the sediment and those detected in the oyster $(0.64$ and $0.80, \alpha=0.65)$. While a moderately negative correlation resulted between $\mathrm{Cd}$ and $\mathrm{Pb}$ in water and those metals in the oyster $(-0.45$ and $-0.34, \alpha=0.65)$. Metal concentrations in tissues also depicted statistically significant correlations, from moderate to high, related to the length, condition index, salinity, $\mathrm{pH}$, oxygen, and temperature (Table 3). Salinity was correlated with $\mathrm{Pb}$ and $\mathrm{Cr}$ concentrations in the oyster $(\mathrm{r}=0.60)$. Length and condition index correlated positively with $\mathrm{Cd}(\mathrm{r}=0.62$ and 0.56 , respectively). The condition index also correlated well with $\mathrm{Pb}$ concentrations in the oyster $(\mathrm{r}=0.64)$.

TABLE 3

Correlation coefficients between biometric and environmental variables and metal concentrations in C. virginica from Mandinga Lagoon, Veracruz, Mexico

Length

Weight

Condition Index

Salinity

$\mathrm{pH}$

Oxygen

Temperature

Metals in water

Metals in sediment

* Statistical significance.

Histology: Histological analysis of indigenous organisms revealed damage in near 50\% of the oysters digestive tract, digestive diverticulum, gonad, and connective tissue. Edema, hyperplasia of epithelial cells in the tubules, presence of brown vesicles, and an increase in hemocytes and necrosis, correlated with environmental pollutants, such as $\mathrm{Cd}(\mathrm{r}=0.63$, $\alpha$ 0.67), $\mathrm{Pb}(\mathrm{r}=0,67, \alpha 0.67)$, and $\mathrm{Cr}(\mathrm{r}=0.57, \alpha$

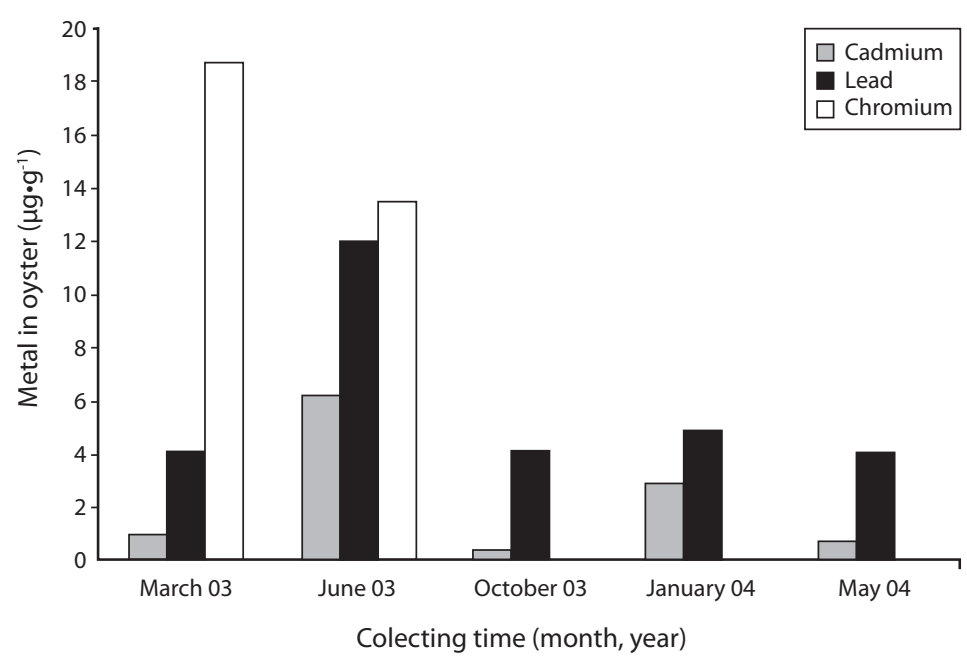

Fig. 3. Concentration of metals in the tissue of the oyster Crassostrea virginica. 
0.67). Figure 4 shows lesions of the digestive gland: loss of epithelia of the tubules (Fig. 4a), brown vesicles present in the connective tissue (Fig. 4b), and hemocyte infiltration (Fig. 4c, d). The damaged organisms presented atrophy of epithelia in more than $80 \%$ of the tubules; however, in a small percentage of tubules $(5 \%)$ epithelia persisted.

The prevalence of these lesions was evaluated in organisms subjected to detoxification, observing a larger number of tubule epithelia cells and brown vesicles in the connective tissue surrounding the tubules, as well as an increase in the hemocytic response with respect to the depuration time. At day 21 of the depuration period, the increase in tubules with epithelia was $11 \%$, brown vesicles increased from 32 in natural organisms to more than 60 in the organisms subjected to detoxification; infiltration of hemocytes was, from moderate to high, in the periphery of the tubules towards the connective tissue, hemocytic response was higher in organisms in the detoxification stage $(20 \%)$ with respect to natural oysters $(10 \%)$. $\mathrm{Cd}$ was not eliminated during depuration time $\left(5 \mu \mathrm{g} \cdot \mathrm{g}^{-1}\right)$.

\section{DISCUSSION}

The results of heavy metals concentrations found were similar to those obtained by other authors (Villanueva \& Botello 1998, Botello et al. 2001, Sobrino-Figueroa et al. 2007), however, other studies have reported an inverse correlation (Gold-Bouchot et al. 1997). These findings suggest that metal levels in the lagoon sediment represent a potential pollution source for the benthic organisms.

The oyster biometrical parameters and the lagoon salinity had no statistical differences between samplings. Weight and condition index were allometrically acceptable; so all organisms in all experiments were in the best conditions.
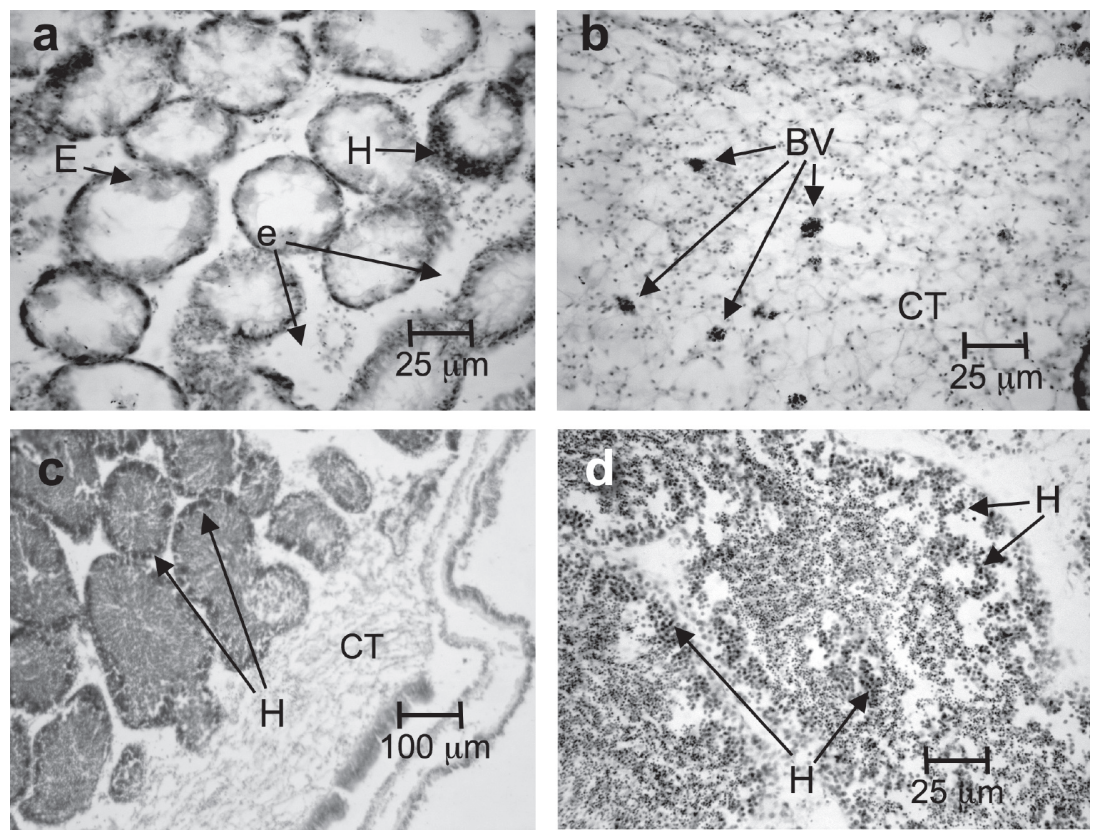

Fig. 4. Histopathological sections of the oyster Crassostrea virginica from the Mandinga lagoon, Veracruz, Mexico. a. Tubules of the digestive gland with edema (e), epithelia (E) and presence of hemocytes $(\mathrm{H})$. b. Connective tissue showing brown vesicles (BV). c. Transversal section of a gonad showing peripheral increase of hemocytes. d. Infiltration of hemocytes in connective tissues. Hematoxylin-eosin stain. 
Winstead (1998) already reported atrophy of the digestive tubules and loss of epithelia as indicators of stress. Zaroogian \& Yevich (1994) reported an increase in the number of brown cells related to the inflammatory response. Results in this study suggest that both the presence of brown vesicles and the hemocytic reaction are specific responses of the detoxification process and tissue recovery. Other authors have pointed out that the appearance and increase in brown vesicles, together with hemocytes at the inflammation site, represent mechanisms of pollutant incorporation, accumulation, and detoxification (Engel 1999).

This metal generally produces saturation responses, which could explain why the levels acquired in the lagoon were not eliminated during the detoxification periods tested, despite the fact that the mean life span of $\mathrm{Cd}$ under laboratory conditions has been estimated to be 21 days (Guzmán-García 2001). Other authors, such as Greig \& Wenzloff (1978), stated that the organisms subjected to depuration from a polluted natural environment to a clean one reduce their depuration rate because metallothioneins (proteins with high affinity for $\mathrm{Cd}$ ) are able to bind the metal and accumulate it in amorphous granules (brown vesicles), inside the cells in a non-toxic manner.

In the case of bivalves, accumulation of metals is produced through feeding, by incorporating the bioavailable forms of the metal (Rainbow et al. 1990). The nature of the digestive gland lesions suggests a prolonged contact with the pollutants through the oral route and the inability to eliminate them. The histopathological observations can be related to stressing environmental factors, such as temperature, salinity, and metal concentrations in the water and/or sediment (Winstead 1998). Damage was associated with metal concentrations in the following order $\mathrm{Pb}>\mathrm{Cd}>\mathrm{Cr}$, however, there are other pollutants not considered in this study that could be affecting the tissues. The histopathological analysis suggests a recovery of tissues and a greater activation of the detoxification processes in $C$. virginica. It is necessary to continue assessing the detoxification process in the laboratory and pursues the analysis of further tissue regeneration.

We suggest that the rainy season fosters resuspension of $\mathrm{Cr}$ and $\mathrm{Cd}$ from the sediment, which could be the cause of the concentrations found in the water. In contrast, during the first semester of the year, the high concentrations of $\mathrm{Cr}, \mathrm{Cd}$ and $\mathrm{Pb}$ in the sediment can be related to the bioaccumulation of these metals in the oyster. The concentrations of metals and their effects on bivalves are risk indicators; therefore, frequent monitoring and the application of measures to improve the quality of the system under study are of great relevance.

This study shows that the combined use of metal determination and histological biomarkers are useful tools that allow the visualization of a complete map of environmental conditions.

\section{REFERENCES}

Agemian, H. \& A.S.Y. Chau. 1976. Evaluation of extraction techniques for determination of metals in aquatic sediments. Analyst 101: 761-767.

Borgmann, U. \& W.P. Norwood. 2002. Metal bioavailability and toxicity through a sediment core. Environ. Pollut. 116: 159-168.

Botello, A.V., B.L. Calva \& V.G. Ponce. 2001. Polycyclic aromatic hydrocarbons in sediments from coastal lagoons of Veracruz State, Gulf of Mexico. Bull. Environ. Contam. Toxicol. 67: 889-897.

Castrejón, O.L., D.D. Porras \& C.S. Band. 1994. Cultivo de alimento vivo para la acuicultura. Universidad del Mar, Oaxaca, Mexico.

Chavin, W. 1973. Teleostean endocrine and paraendocrine alterations of utility in environmental studies, p. 199238. In W. Chavin (ed.). Responses of fishes to environmental change. Thomas-Springfield, Chicago, USA.

Engel, D.W. 1999. Accumulation and cytosolic partitioning of metals in the American oyster Crassostrea virginica. Mar. Environ. Res. 47: 89-102.

EPA (Environmental Protection Agency). 1984. Ambient water quality criteria for cadmium. Washington D.C., USA. 
Everitt, B.S. 1992. The analysis of contingency tables. Chapman \& Hall, London, UK.

Gold-Bouchot, G., M. Zavala-Coral, O. Zapata-Perez \& V. Ceja-Moreno. 1997. Hydrocarbon concentrations in oysters (Crassostrea virginica) and recent sediments from three coastal lagoons in Tabasco, Mexico. Bull. Environ. Contam. Toxicol. 59: 430-437.

Greig, R.A. \& D.R. Wenzloff. 1978. Metal accumulation and depuration by American oyster, Crassostrea virginica. Bull. Environ. Contam. Toxicol. 20: 499-504.

Guzmán-García, X. 2001. Toxicocinética de cadmio y daño histopatológico en ostión Crassostrea virgínica en condiciones de ayuno y alimentación. Universidad Autónoma Metropolitana, Mexico.

Hetzel, E.W. \& D.A. Wright. 1983. The use of RNA/ DNA ratios as an indicator of nutritional stress in the american oyster, Crassostrea virginica. Estuaries 6: 259-259.

Howard, D. \& C. Smith. 1983. Histological techniques for marine bivalve mollusks. NOAA Technical Memorandum NMFS-F/NEC-25:NOOA, Woods Hole, Massachusetts, USA.

IAEA/UNEP/FAO/IOC. 1984. Determination of total cadmium, zinc, lead and copper in selected marine organisms by flameless atomic absorption spectrophotometry. International Atomic Energy Agency.

Krishnakumar, P.K., E. Casillas \& U. Varanasi. 1994. Effect of environmental contaminants on the health of Mytilus edulis from Puget-Sound, Washington, USA. 1. Cytochemical measures of lysosomal responses in the digestive cells using automatic image-analysis. Mar. Ecol. Prog. Ser. 106: 249-261.

Long, E.R., D.D. Macdonald, S.L. Smith \& F.D. Calder. 1995. Incidence of adverse biological effects within ranges of chemical concentrations in marine and estuarine sediments. Environ. Manag. 19: 81-97.

Lucas, A. \& P.G. Beninger. 1985. The use of physiological condition indexes in marine bivalve aquaculture. Aquaculture 44: 187-200.

Luna, M., V.O. Rendón \& L.G. Alpuche. 2002. Presencia de plomo en agua y ostión en las lagunas de Alvarado y la Mancha, p. 96-111. In A.P. Guzmán, B.C. Quiroga, L.C. Díaz, C.D. Fuentes, M.C. Contreras \& G. Silva López (eds.). La pesca en Veracruz y sus perspectivas de desarrollo. SAGARPA-UV, Veracruz, Mexico.
Malo, B.A. 1977. Partial extraction of metals from aquatic sediments. Environ. Sci. Technol. 11: 277-282.

Mann, R. 1978. A comparison of morphometric, biochemical and physiological indexes of condition in marine bivalve molluscs, p. 484-497. In J.H. Thorp \& J.W. Gibbons (eds.). Energy and environmental stress in aquatic systems, Washington, USA.

Nauen, C.C. 1983. Compilation of legal limits for hazardous substances in fish and fishery products. FAO, Rome, Italy.

Paez-Osuna, F., J.I. Osuna-Lopez, G. Izaguirre-Fierro \& H.M. Zazueta-Padilla. 1993. Heavy metals in oysters from a subtropical coastal lagoon associated with an agricultural drainage basin. Bull. Environ. Contam. Toxicol. 50: 696-702.

Palacios Fest, M. \& R. Vargas Rancel. 2002. Pesquería de ostión, p. 96-111. In A.P. Guzmán, B.C. Quiroga, L.C. Díaz, C.D. Fuentes, M.C. Contreras \& G. Silva López (eds.). La pesca en Veracruz y sus perspectivas de desarrollo. SAGARPA-UV, Mexico.

Rainbow, P.S., D.J.H. Phillips \& M.H. Depledge. 1990. The significance of trace-metal concentrations in marine-invertebrates-a need for laboratory investigation of accumulation strategies. Mar. Pollut. Bull. 21: $321-324$

SEPESCA-Secretaría de Pesca. 1988. Manual Técnico para la operación de centros acuícola productores de ostión. SEPESCA, Mexico.

Shumway, S.E. \& R.K. Koehn. 1982. Oxygen-consumption in the american oyster Crassostrea virginica. Mar. Ecol. Prog. Ser. 9: 59-68.

Sobrino-Figueroa, A.S., C. Caceres-Martinez, A.V. Botello \& G. Nunez-Nogueira. 2007. Effect of cadmium, chromium, lead and metal mixtures on survival and growth of juveniles of the scallop Argopecten ventricosus (Sowerby II, 1842). J. Environ. Sci. Health. Tox. Hazard. Subst. Environ. Eng. 42: 1443-1447.

Villanueva, S.F. \& A.V. Botello. 1998. Metal pollution in coastal areas of Mexico. Rev. Environ. Contam. Toxicol. 157: 53-94.

Winstead, J.T. 1998. A histological study of digestive tubules in intertidal and subtidal oysters, Crassostrea virginica, collected at high and low tides. J. Shellfish Res. 17: 275-279.

Zaroogian, G. \& P. Yevich. 1994. The nature and function of the brown cell in Crassostrea virginica. Mar. Environ. Res. 37: 355-373. 